\title{
Please Copy
}

Annual Meeting - August 28-31, 1997

Proposal Deadline - November 15, 1996

\section{ORGANIZED PANEL PROPOSAL}

PRoposal FoR:

Panel

ROUNDTABLE

1. Panel title and Description (PLEASE TYPE, PRINT OR ATTACHI

2. SUBMISSION INSTRUCTIONS:

Please forward this proposal to the following Division[s] of the Program Committee (Limit 2)

1)

2)

3. HAVE YOU PERSONALLY CONTACTED ALL PROPOSED PARTICIPANTS AND SECURED THEIR CONSENT TO PARTICIPATE?

$$
\text { YES } \square \quad \text { No } \square
$$

4. HAVE YOU INFORMED EACH PARTICIPANT OF THE PREREGISTRATION REQUIREMENT?

$$
\text { YES } \square \quad \text { No } \square
$$

5. HAVE YOU INFORMEd EACH PARTICIPANT OF THE PAPER DELIVERY REQUIREMENT?

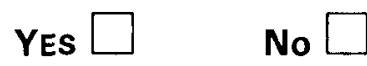

